\title{
DYNAMIC TESTS ON PTFE SLIDING LAYERS UN DER EARTHQUAKE CONDITIONS
}

\author{
R. G. Tyler*
}

\section{ABSTRACT}

The first part of a programme to assess the characteristics of PTFE sliding bearings during earthquake motions is described. Tests were performed on pure PTFE elements sliding on stainless steel.

Representative normal loads were applied together with a sliding action, giving a maximum acceleration of $0.2 \mathrm{~g}$ and a maximum velocity of $38 \mathrm{~cm} / \mathrm{sec}$, i.e. motions equivalent to a moderate to severe earthquake.

At $0^{\circ} \mathrm{C}$ friction was found to have maximum coefficients which fell from 17 to $13 \%$ as the normal pressure was increased from 15 to $25 \mathrm{MN} / \mathrm{m}^{2}$. At $20^{\circ} \mathrm{C}$ corresponding values were reduced to 15 and $10 \%$. Maximum friction generally occurred in the first cycle of loading after which values fell. After 5 cycles the range was typically 9 to $5 \%$.

Tests on lubricated PTFE layers showed coefficients of friction less than 2\% under the above test conditons; the maintenance of this low. value over the years would depend on the effective retention of the grease.

It is possible that, by careful design of bearings for higher pressures, and utilizing filled PTFE materials, lower overall friction values for the dry condition may be achieved.

\section{INTRODUCT ION}

Bearings incorporating PTFE\# ${ }^{\#}$ siding layers are commonly used in bridge applications to accommodate the comparatively slow movements arising from temperature changes and the creep and shrinkage of concrete. For this application coefficients of friction as low as 0.03 are common for polished stainless steel sliding on PTFE. During an earthquake, however, much faster sliding speeds may be experienced. Research carried out so far in other parts of the world has indicated that friction increases with velocity, but no tests have been reported at for the high bearing pressures and velocities which would occur during an earthquake, possibly because a short bearing life would be expected and there would be little application in the mechanical engineering field.

The purpose of the tests described was to determine coefficients of friction at velocities and accelerations representative of those which occur during moderate to severe earthquakes. This will enable lateral forces on bridge piers and abutments and the level of the associated damping of oscillations to be evaluated. The knowledge of friction characteristics also enables this type of bearing to be considered as part of base isolation systems for buildings. It was not possible to use programmed earthquake motions for the tests, the only motion available being sinusoidal obtained from an adjustable eccentric on the rear drive of a bulldozer adapted for linear dynamic testing.

* Physics and Engineering Laboratory, Department of Scientific and Industrial Research, Lower Hutt.

\section{TEST EOUIPMENT}

Pieces of sheet PTFE, $140 \mathrm{~mm}$ square by $3.35 \mathrm{~mm}$ thick, were obtained from a manufactuerer of sliding bridge bearings in New Zealand. A sliding surface with dimpled recesses was used as it was desired to determine the effect of silicone grease on the coefficient of friction. The function of the recesses was to retain the grease and to introduce more grease to the slidino surfaces durina wear of the PTFE, a method employed by this manufacturer for the purpose of achieving a low coefficient of friction.

A sliding rig, shown schematically in Fig. 1, was fabricated to enable the tests to be carried out in the bulldozer testing machine. The stainless steel surfaces on either side of the central plate were supplied and fixed by the bearing manufacturer. The stainless steel was $1.6 \mathrm{~mm}$ thick and was screwed and bonded to the central plate. The alloying composition was $18 \%$ chrome, $10 \%$ nickel and $3 \%$ molybdenum and the sliding surface was polished to between 0.05 and $0.15 \mu \mathrm{m}$ CLA.

The sandwich of two pieces of PTFE, one above and one below the central plate, enabled friction to be obtained from two sliding surfaces simultaneously. A hydraulic jack of $500 \mathrm{kN}$ capacity was used to simulate the normal loading, and a pressure gauge on the pump to determine load values. An XY plotter was employed to record the frictional force/stroke characteristic and a pen recorder

\# PTFE or polytetrafluoroethylene, which is known under the trade name Teflon, is described as a fluorocarbon resin. 
for the force time characteristic, on which was superimposed a temperature record from a thermocouple in the central plate immediately under one of the stainless steel layers.

\section{TEST METHOD}

The bulldozer eccentric was set at its maximum stroke which gave $\pm 72 \mathrm{~mm}$ at the PTFE sliding surfaces. As a moderate to severe earthquake was considered to be equivalent to about 5 cycles at the maximum stroke, the aim for each test was to complete at least that number of cycles, although for some of the tests as many as 30 were completed. Six sets of tests were carried out as Iisted in Table 1 . In general, for each set of tests, one test was carried out at a slow speed in the range 0.14 to 0.30 $\mathrm{Hz}$, followed by another at the faster speed of $0.83 \mathrm{~Hz}$. Two tests were carried out at intermediate speeds, and further tests carried out at the fast speed as required. In most instances the vertical load was applied just before testing commenced, but in other cases the load was held on for a few hours, or overnight, prior to testing, as indicated in the table.

The PTFE layers were changed after each set of tests except for the low and medium tests, when one pair of pieces sufficed for the two sets. In most instances, by the time the pieces were changed, the dimpled recesses had almost worn away. Wear occurred by scuffing of the surface, producing thin "snowflakes" of PTFE which were carried out on the slider. The slider was cleaned and polished after each set of tests to maintain its condition as supplied.

The first four sets of tests were carried out on dry PTFE at room temperature at four different bearing pressures to cover the range likely to be encountered in normal bridge applications. These pressures were initially $7.8,15.6,23.3$ and $31.0 \mathrm{MN} / \mathrm{m}^{2}$, the values decreasing by up to $14 \%$ as the tests proceeded as the dimpled recesses in the PTFE wore away. Actual values for a particular test are estimated in column 4 of Table 1, depending on the wear which had occurred up to that time. For the tests at $31 \mathrm{MN} / \mathrm{m}^{2}$ the PTFE layers were cut down to $140 \times 105 \mathrm{~mm}$ in order to achieve the higher pressure for the given jack capacity.

Normal pressures in excess of $25 \mathrm{MN} / \mathrm{m}^{2}$ are not usually employed by bridge bearing manufacturers because of the tendency of PTFE to creep under load while the frictional coefficient increases as the pressure is reduced so that pressures are rarely under $15 \mathrm{MN} / \mathrm{m}^{2}$. Traffic loadings increase the pressures, but only as a transient loading and this is not considered to influence creep.

The fifth set of tests was carried out at the fairly typical pressure of $23.3 \mathrm{MN} / \mathrm{m}^{2}$ on dry PTFE layers under freezing conditions produced by insulating the friction rig with a box of expanded polystyrene and packing dry ice around the rig for five hours prior to the tests. This test showed that friction increased as the temperature dropped, thus giving a greater load on bridge piers and it was not felt necessary to carry out tests at elevated temperatures, as design would be controlled by the cold condition.
In the sixth set of tests silicone grease supplied by the bearing manufacturers was spread over PTFE layers, $140 \times 105 \mathrm{~mm}$ in size, to fill the dimpled recesses and a test carried out at $23.3 \mathrm{MN} / \mathrm{m}^{2}$. Very little friction was apparent over 30 cycles of testing, with little temperature rise, and it appeared that testing would go on for a long time before any change of condition came about. Accordingly the test was stopped and the rig stripped and cement dust added to the grease on each PTFE layer in order to simulate the worst condition which could conceivably be experienced on a building site. On testing again, friction peaked to a high value of about $20 \%$ but settled down to $10 \%$ after the first half cycle. After 30 cycles the test was stopped and the rig allowed to cool to room temperature. and a further test carried out, followed by another at the high pressure of $31 \mathrm{MN} / \mathrm{m}^{2}$.

In a seventh set of tests not listed in Table $I$ new pieces of PTFE were inserted in the rig and cement dust sprinkled on the sliding layers prior to reassembly with no qrease added. A first test at the fast speed of $0.83 \mathrm{~Hz}$ produced an overload condition on the load cell, although this was not realised at the time. The test was repeated after stripping the rig and adding more cement dust, which produced, on retesting, a complete seizure and a fracture of the load cell at a frictional force of over $200 \mathrm{kN}$, i.e. $40 \%$ friction; testing was discontinued.

It was thought conceivable prior to this test, that sliding was made possible by a shearing action at the PTFE surface, and that surface condition would not affect the sliding of dry bearings, but the tests showed that sliding is progressively affected by the addition of dust to the surfaces and that dirty site conditions should therefore be avoided. It is nevertheless considered that the condition set up for the test was an artificial one in that dust would never be sprinkled on the bearing surfaces before mating them together, but rather that dust on the upper stainless steel surface of a bridge bearing was likely to be swept by the edge of the bearing, so that frictional conditions of the severity of those found in the test were not likely to be experienced in practice.

The thicknesses of the pieces of PTFE were measured before testing and after removal from the rig as indicated in Table 1. The thickness was measured on flat areas away from the dimpled recesses.

\section{RESULTS}

The results are summarised in Table 1. Representative load-displacement loops for the four different pressure values are given in Figs. 2 and 3 , and for the "cold" test and lubricated tests in Fig. 4. All the loops are plotted to the same scales. Where, in the very high pressure tests, smaller pieces of PTFE were used in order to achieve a higher pressure for the maximum jack load, for purposes of comparison the loop ordinates have been scaled up to give the forces which would have occured on the standard size of specimen. Thus values scaled from Fig. 3, tests 10 and 13, Fig. 4, 
tests 20, 21, and 22, and Fig. 5, test 10, do not agree with values quoted in Table 1 .

Representative load-time records for the four pressures, which indicate the variation of frictional force with the number of completed cycles are given in Fig. 5 . Temperature rise recorded by the single thermocouples in the centre plate are also given.

In Fig. 6 maximum values of coefficient of. friction for each test are plotted against bearing pressure, these usually occurring during the peaking up of friction during the first cycle of loading, except for some of the slow speed tests were friction built up over the first few cycles and appeared to depend more on peak velocity than initial acceleration. It is apparent that, overall, frictional forces are greater at the faster bulldozer speed than at the slower, i.e. friction is velocity dependent. However, whether friction actually depends on the value of acceleration required to achieve the peak velocity is debatable. Values obtained during tests using cement dust are not plotted. Temperatures at the start of each test are also recorded on the graphs and it is seen that friction is greater at the lower temperatures. The dotted straight line passing through the points obtained in the "cold" tests thus represents the maximum friction which is likely to occur in sliding bridge bearings employing pure PTFE layers in New Zealand, on the assumptions that the temperature will drop to about $0^{\circ} \mathrm{C}$ at night in winter, and that the earthquake will generate roughly the same accelerations and velocities as those in the test. For applications in buildings a further chaindotted line has been drawn on Fig. 6 , representing likely maximum friction values occurring at $20^{\circ} \mathrm{C}$. The results show that greater values of frictional force were obtained at the fastest bulldozer speed; ideally, relationships between friction and acceleration, and friction and speed, should be obtained in more sophisticated testing.

The wear rate was greatest at the highest pressure. The rate was about $0.02 \mathrm{~mm}$ per cycle at $31 \mathrm{MN} / \mathrm{m}^{2}$ (Table 1 ); thus taking a moderate to severe earthquake as about equivalent to 5 cycles at $\pm 75 \mathrm{~mm}$ at least $0.1 \mathrm{~mm}$ of wear would need to be allowed for each earthquake.

For the greased type of PTFE bearing friction is very much lower at less than 2\% and in consequence, wear, althouch not specifically measured during the tests with grease only, will be much less. The maintenance of this reduced value of friction over the years will depend on the retention of the grease in an effective lubricating condition. This type of bearing has been used in Europe for about a decade but the author has not seen mention of its performance after a period of time. Nevertheless these tests showed that, even with a generous measure of cement dust added, friction settled down to a value no greater than that obtained in the dry tests (Table 1), whereas complete seizure occurred when the dust was added without the grease.

Maximum values of friction for the first peak of the sixth cycle after the commencement of each test are plotted in
Fig. 7. There is less scatter than for the first cycle and a mean line, representing damping friction which could be relied on during the course of an earthquake, has been drawn through the centre of the points. There is a further decay after the sixth cycle as shown up in Fig. 5, but the decay is diminishing.

Although there was a temperature rise in the centre plate of over $100^{\circ} \mathrm{C}$ for some of the tests, while the PTFE surface temperatures must have been higher it is not thought that this will be a problem during an earthquake because many smaller cycles would be mixed in with larger ones. PTFE is stable to over $300^{\circ} \mathrm{C}$.

NET FRICTIONAL FORCE ON BEARINGS RELATED TO PRESSURE

The curves given in Figs. 6 and 7 show that the coefficient of friction goes down as the bearing pressure rises. On the other hand there must be less variation in the total frictional force, $F$, generated at the bearing, since it depends on the product of these two quantities.

Evidently $F=\mu \mathrm{pA}$

where $\mu=$ coefficient of friction

$$
\begin{aligned}
& \mathrm{p}=\text { pressure }\left(\mathrm{MN} / \mathrm{m}^{2}\right) \\
& A=\text { area }\left(\mathrm{m}^{2}\right)
\end{aligned}
$$

Values for the tests on dry PTFE (from the curves in Figs. $6 \& 7$ ) are presented in Table 2 .

Since the produce $\mu p$ is the frictional force per unit area of bearing, it is apparent that there is only a maximum variation of about $13 \%$ in frictional force over the working pressures employed for bridge bearings (viz. $15-25 \mathrm{MN} / \mathrm{m}^{2}$ ). This suggests that, at these pressures, the friction force depends more on the loaded area of PTFE than on the value of the load, i.e. PTFE does not behave according to the coulomb's law of friction.

\section{COMMENT}

For the rance of bearing pressures commonly used in bridge construction, viz. 15-25 $\mathrm{MN} / \mathrm{m}^{2}$, the corresponding range of maximum friction values at $0^{\circ} \mathrm{C}$ is 17 to $13 \%$ for the conditions pertaining in the tests. As this range of values is much greater than the commonly quoted value of 3\% for static friction, it is clear that the forces on piers and abutments which occur during an earthquake will be significantly greater than those occurring during temperature movements. For applications within buildings, when the temperature remains at about $20^{\circ} \mathrm{C}$, the corresponding range of friction values is from 15 to $10 \%$.

If a structure supported on PTFE bearings can survive the initial shock, then the bearings provide useful damping for the oscillations which follow. After 5 cycles friction is reduced to the range 9 to 5\% for the range of bearing pressures quoted above. A centering action may need to be provided because of the danger of progressive movement in one direction. 
This may be provided by the use of some appropriately located laminated rubber bearings, or, in the longitudinal direction, by pinning the structure to the tops of slender columns.

The wear rate is acceptable at $0.1 \mathrm{~mm}$ per earthquake since only one or two earthquakes would be expected in the life of the structure, and wear may be controlled by day to day temperature movements. However, maximum friction values for this dry material are rather high, and the possibility arises that, by the careful design of the bearings for higher pressures by introducing filled PTFE materials, the friction values can be reduced.

The wear rate, $t$, is given by the well known expression:

$t=\mathrm{kPVT}$

where $\mathrm{k}=\mathrm{a}$ wear factor which depends on the filler material

$\mathrm{P}=$ pressure

$\mathrm{V}=$ velocity

$\mathrm{T}=$ time

The value of $\mathrm{k}$ is reduced by such fillers as fibre glass, graphite or bronze. Thus higher PV values are possible for the same wear rate, while, overall, friction is reduced at higher pressures.

\section{CONCLUSIONS}

1. Friction increases with speed but whether or not friction depends more on the acceleration required to produce this speed, or the speed itself, is debatable. At the faster bulldozer speed peaking of the frictional force appeared to depend on initial acceleration or a stick-slip. characteristic, but, at the slower, on velocity at the centre of the stroke.

2. Friction increases as the temperature is lowered. For pure PTFE sliding on stainless steel and the conditions pertaining in the test, viz. a maximum acceleration of $0.2 \mathrm{~g}$ and a peak velocity of $38 \mathrm{~cm} / \mathrm{sec}$, the peak friction at $0^{\circ} \mathrm{C}$, which occurred during the first cycle of loading, was in the range 17 to $13 \%$ for the correspondina pressure rancre of 15 to $25 \mathrm{MN} / \mathrm{m}^{2}$. At $20^{\circ} \mathrm{C}$ the corresponding range was 15 to $10 \%$.

3. Should the structure survive the initial peak frictional forces during an earthquake, then the bearings will provide useful damping for the oscillations which follow. For the range of pressures quoted above, the corresponding range of frictional forces after 5 cycles will be 9 to 5\%, although this value will further diminish as the bearing is worked.

4. The lubricated type of bearing in which grease is retained in recesses in the PTFE produced frictional values below $2 \%$ for the same test conditions. The maintenance of the very low value of frictional force over the years will depend on the retention of grease in a condition which will ensure lubrication of the bearing.
5. The effect of cement dust placed between the bearing surfaces prior to assembly was to cause seizure of the bearing. It is considered, however, that, although dust is detrimental to performance, the test condition was artificial in that, in practice, any dust which settles on the stainless steel plate is likely to be swept off by the edges of the PTFE elements.

6. It is possible that, by careful design of bearings for higher pressures, and by the introduction of filled PTFE materials, lower overall friction values in the dry condition may be achieved.

Paper received 9 September, 1977 
TABLE 1

FRICTION VALUES

\begin{tabular}{|c|c|c|c|c|c|c|c|c|c|c|c|c|c|c|}
\hline \multicolumn{2}{|l|}{ Test } & \multirow{3}{*}{$\begin{array}{l}\text { Date } \\
\\
1\end{array}$} & \multirow{3}{*}{$\begin{array}{l}\text { Time } \\
2\end{array}$} & \multicolumn{2}{|c|}{$\begin{array}{l}\text { Bearing Press. } \\
\left(\mathrm{MN} / \mathrm{m}^{2}\right)\end{array}$} & \multirow{3}{*}{$\begin{array}{l}\text { Vertical } \\
\text { jack load } \\
\quad(\mathrm{kN}) \\
\\
5\end{array}$} & \multirow{3}{*}{$\begin{array}{c}\text { Speed } \\
(\mathrm{Hz}) \\
\\
6\end{array}$} & \multicolumn{2}{|c|}{$\begin{array}{r}\text { Peak * } \\
\text { friction }\end{array}$} & \multirow{2}{*}{\multicolumn{2}{|c|}{$\begin{array}{l}\text { Maximum } \\
\text { friction } 6 \text { th } \\
\text { cycle }\end{array}$}} & \multirow{3}{*}{$\begin{array}{l}\text { No. of } \\
\text { cycles } \\
\text { completed } \\
11\end{array}$} & \multirow{3}{*}{$\begin{array}{l}\text { Temperature } \\
\text { range in } \\
\left.\text { slider ( }{ }^{\circ} \mathrm{C}\right) \\
12\end{array}$} & \multirow{3}{*}{$\begin{array}{l}\text { Thickness } \\
\text { of } \\
\text { PTFE layer } \\
\text { (mm) } \\
13\end{array}$} \\
\hline & & & & \multirow{2}{*}{$\begin{array}{c}\text { Nominal } \\
3\end{array}$} & \multirow{2}{*}{$\begin{array}{l}\text { Est. } \\
\text { true } \\
\text { value } \\
\quad 4\end{array}$} & & & & & & & & & \\
\hline & No. & & & & & & & $\begin{array}{c}\text { Force } \\
(\mathrm{kN}) \\
7\end{array}$ & $\begin{array}{l}1 \\
8 \\
8\end{array}$ & $\begin{array}{c}\text { Force } \\
(\mathrm{kN}) \\
9\end{array}$ & $\begin{array}{r}4 \\
8 \\
10\end{array}$ & & & \\
\hline $\begin{array}{l}\text { Set } 1 \text { High } \\
\text { pressure }\end{array}$ & $\begin{array}{l}1 \\
2\end{array}$ & $\begin{array}{c}17.2 .77 \\
" ~\end{array}$ & $\begin{array}{l}10.30 \\
10.45\end{array}$ & $\begin{array}{c}23.3-20.0 \\
"\end{array}$ & $\begin{array}{l}23.0 \\
22.0\end{array}$ & $\begin{array}{c}385 \\
"\end{array}$ & $\begin{array}{l}0.14 \\
0.83\end{array}$ & $\begin{array}{l}53.5^{3} \\
89.0\end{array}$ & $\begin{array}{r}7.0 \\
11.6\end{array}$ & $\begin{array}{l}42 \\
54 \\
\text { Total }\end{array}$ & $\begin{array}{c}5.5 \\
7.0 \\
\text { cycles }\end{array}$ & $\begin{array}{r}8 \\
+\quad \frac{7}{15}\end{array}$ & $\begin{array}{l}20 \text { start } \\
30 ? \quad " \\
\text { Net wear }+\end{array}$ & $\begin{array}{l}3.35 \\
3.18 \\
0.17\end{array}$ \\
\hline $\begin{array}{ll}\text { Set } 2 & \text { Low } \\
& \text { pressure }\end{array}$ & $\begin{array}{l}3 \\
4 \\
5\end{array}$ & $\begin{array}{c}23.2 .77 \\
" 1 \\
24.4 .77\end{array}$ & $\begin{array}{l}10.30 \\
10.40 \\
11.05^{+} \\
\end{array}$ & $\begin{array}{c}7.8-6.7 \\
" 1 \\
"\end{array}$ & $\begin{array}{l}7.8 \\
7.6 \\
7.5\end{array}$ & $\begin{array}{c}128 \\
" \\
"\end{array}$ & $\begin{array}{l}0.21 \\
0.83 \\
0.83\end{array}$ & $\begin{array}{l}34.6^{3} \\
45.8 \\
45.3\end{array}$ & $\begin{array}{l}13.5 \\
17.8 \\
17.6\end{array}$ & $\begin{array}{l}34.6 \\
33.6 \\
36.1\end{array}$ & $\begin{array}{l}13.5 \\
13.1 \\
14.1\end{array}$ & $\begin{array}{l}7 \\
6 \\
6\end{array}$ & $\begin{array}{l}20 \text { to } 54 \\
31 \text { to } 75 \\
20 \text { to } 68\end{array}$ & 3.35 \\
\hline $\begin{array}{l}\text { Set } 3 \text { Medium } \\
\text { pressure }\end{array}$ & $\begin{array}{l}6 \\
7 \\
8 \\
9\end{array}$ & $\begin{array}{c}24.4 .77 \\
" \\
" \\
"\end{array}$ & $\begin{array}{l}11.25 \\
11.35 \\
11.45 \\
14.00^{\#}\end{array}$ & $\begin{array}{c}15.6-13.4 \\
" \\
"\end{array}$ & $\begin{array}{l}14.8 \\
14.6 \\
14.3 \\
14.0\end{array}$ & $\begin{array}{l}256 \\
" \\
" \\
"\end{array}$ & $\begin{array}{l}0.30 \\
0.83 \\
0.50 \\
0.83\end{array}$ & $\begin{array}{l}66.1 \\
61.0 \\
53.9 \\
79.3\end{array}$ & $\begin{array}{l}12.9 \\
11.9 \\
10.5 \\
15.5\end{array}$ & $\begin{array}{l}43.7 \\
43.7 \\
40.7 \\
50.8 \\
\text { Total }\end{array}$ & $\begin{array}{c}8.5 \\
8.5 \\
7.9 \\
9.9 \\
\text { cycles }\end{array}$ & $\begin{array}{r}6 \\
6 \\
5 \\
+\frac{11}{47}\end{array}$ & $\begin{array}{l}32 \text { to } 91 \\
42 \text { to } 100 \\
68 \text { to } 110 \\
21 \text { to } 111 \\
\text { Net } \text { Wear } \rightarrow\end{array}$ & $\frac{3.05}{0.30}$ \\
\hline $\begin{aligned} \text { Set } 4 \text { very } & \\
& \text { high } \\
& \text { pressure }\end{aligned}$ & $\begin{array}{l}10 \\
11 \\
12 \\
13 \\
14\end{array}$ & $\begin{array}{c}28.2 .77 \\
" \\
" \\
" \\
"\end{array}$ & $\begin{array}{l}10.30 \\
10.45 \\
10.50 \\
11.40 \\
10.30^{+}\end{array}$ & $\begin{array}{c}31.0-26.7 \\
" \\
" \\
"\end{array}$ & $\begin{array}{l}31.0 \\
30.0 \\
29.0 \\
28.0 \\
27.0\end{array}$ & $\begin{array}{c}385 \\
" \\
" \\
"\end{array}$ & $\begin{array}{l}0.29 \\
0.83 \\
0.48 \\
0.83 \\
"\end{array}$ & $\begin{array}{l}33.3 \\
45.4 \\
42.9 \\
73.6 \\
67.6\end{array}$ & $\begin{array}{l}4.3 \\
5.9 \\
5.6 \\
9.6 \\
8.8\end{array}$ & $\begin{array}{l}33.3 \\
32.3 \\
29.2 \\
42.3 \\
44.8 \\
\text { Total }\end{array}$ & $\begin{array}{c}4.3 \\
4.2 \\
3.8 \\
5.5 \\
5.8 \\
\text { cycles }\end{array}$ & $\begin{array}{r}6 \\
10 \\
6 \\
11 \\
+\frac{10}{43}\end{array}$ & $\begin{array}{l}20 \text { start } \\
30 ? "= \\
40 ? " \\
21 \text { to } 73 \\
19 \text { to } 78 \\
\text { Net Wear }+\end{array}$ & $\frac{2.54}{0.81}$ \\
\hline $\begin{array}{c}\text { Set } 5 \text { "Cold" } \\
\text { at } \\
\text { high } \\
\text { pressure }\end{array}$ & $\begin{array}{l}15 \\
16 \\
17 \\
18\end{array}$ & $\begin{array}{c}3.3 .77 \\
" \\
"\end{array}$ & $\begin{array}{l}14.00 \\
14.10 \\
14.40 \\
14.50\end{array}$ & $\begin{array}{c}23.3-20.0 \\
" \\
"\end{array}$ & $\begin{array}{l}23.3 \\
22.0 \\
21.5 \\
21\end{array}$ & $\begin{array}{l}385 \\
" \\
" \\
"\end{array}$ & $\begin{array}{l}0.83 \\
" \\
" \\
"\end{array}$ & $\begin{array}{r}101.5 \\
98.5 \\
107.7 \\
86.2\end{array}$ & $\begin{array}{l}13.2 \\
12.8 \\
14.0 \\
11.2\end{array}$ & $\begin{array}{l}58.5^{5} \\
56.4^{-4} \\
57.4 \\
56.4 \\
\text { Total }\end{array}$ & $\begin{array}{c}7.5 \\
7.3 \\
7.4 \\
7.3 \\
\text { cycles }\end{array}$ & $\begin{array}{r}4 \\
4 \\
11 \\
+\frac{11}{30}\end{array}$ & $\begin{array}{l}-17 \text { to } 37 \\
12 \text { to } 58 \\
-1 \text { to } 104 \\
12 \text { to } 112 \\
\text { Net Wear } \rightarrow\end{array}$ & $\frac{3.19}{0.16}$ \\
\hline $\begin{array}{l}\text { Set } 6 \text { Grease } \\
" \\
\text { Cement dust add. } \\
" \text { - after cool } \\
" \text { - repeat at } \\
\text { very high press. }\end{array}$ & $\begin{array}{l}19 \\
20 \\
21 \\
22 \\
23\end{array}$ & $\begin{array}{c}4.3 .77 \\
" \\
" \\
"\end{array}$ & $\begin{array}{l}13.00 \\
13.05 \\
13.15 \\
14.15 \\
14.20\end{array}$ & $\begin{array}{c}23.3-20.0 \\
" \\
" \\
" \\
31.0-26.7\end{array}$ & $\begin{array}{l}23.3 \\
" 1 \\
22.5 \\
21.5 \\
27.0\end{array}$ & $\begin{array}{c}289 \\
" \\
" \\
" \\
385\end{array}$ & $\begin{array}{l}0.30 \\
0.83 \\
" \\
" \\
"\end{array}$ & $\begin{array}{r}11.2 \\
7.1 \\
120.0 \\
66.1 \\
62.0\end{array}$ & $\begin{array}{r}1.9 \\
1.2 \\
20.8 \\
11.4 \\
8.1\end{array}$ & $\begin{array}{l}3.6 \\
6.6 \\
29.5 \\
30.5 \\
30.5 \\
\text { Total }\end{array}$ & $\begin{array}{c}0.6 \\
1.1 \\
5.1 \\
5.3 \\
4.0 \\
\text { cycles }\end{array}$ & $\begin{array}{r}4 \\
26 \\
30 \\
4 \\
-\quad \frac{4}{68}\end{array}$ & $\begin{array}{l}20 \text { to } 21 \\
21 \text { to } 34 \\
27 \text { to } 104 \\
20 \text { to } 36 \\
36 \text { to } 52 \\
\text { Net Wear } \rightarrow\end{array}$ & $\frac{3.12}{0.23}$ \\
\hline
\end{tabular}

* Normally for first cycle otherwise index figure gives cycle number.

+ Pressure on all night prior to test.

\# Pressure on $2^{\frac{1}{4}}$ hours prior to test.

$\uparrow$ Estimated value.

$x$ For two surfaces. 
TABLE 2

FRICTIONAL FORCES

\begin{tabular}{|c|c|c|c|c|c|c|}
\hline \multirow{3}{*}{$\begin{array}{c}\text { Pressure } \\
\mathrm{p} \\
\left(\mathrm{MN} / \mathrm{m}^{2}\right)\end{array}$} & \multicolumn{4}{|c|}{ Maximum friction } & \multirow{2}{*}{\multicolumn{2}{|c|}{$\begin{array}{l}\text { Friction after } 5 \\
\text { cycles } 0 \text { to } 20^{\circ} \mathrm{C}\end{array}$}} \\
\hline & \multicolumn{2}{|c|}{$0^{\circ} \mathrm{C}$} & \multicolumn{2}{|c|}{$20^{\circ} \mathrm{C}$} & & \\
\hline & $\begin{array}{l}\mu \\
\frac{\circ}{0}\end{array}$ & $\operatorname{lpp}_{\left(\mathrm{MN} / \mathrm{m}^{2}\right)}$ & $\begin{array}{l}\mu \\
\frac{\circ}{0}\end{array}$ & $\operatorname{mp}_{\left(\mathrm{MN} / \mathrm{m}^{2}\right)}$ & $\begin{array}{l}\mu \\
\frac{8}{8}\end{array}$ & $\operatorname{mp}_{\left(\mathrm{MN} / \mathrm{m}^{2}\right)}$ \\
\hline 10 & 19.5 & 1.95 & 17.7 & 1.77 & 11.8 & 1.18 \\
\hline 15 & 17.3 & 2.59 & 15.5 & 2.21 & 8.8 & 1.32 \\
\hline 20 & 15.0 & 3.00 & 13.2 & 2.64 & 6.6 & 1.32 \\
\hline 25 & 12.8 & 3.40 & 11.0 & 2.73 & 4.8 & 1.20 \\
\hline 30 & 10.5 & 3.15 & 8.7 & 2.61 & 3.4 & 1.02 \\
\hline
\end{tabular}
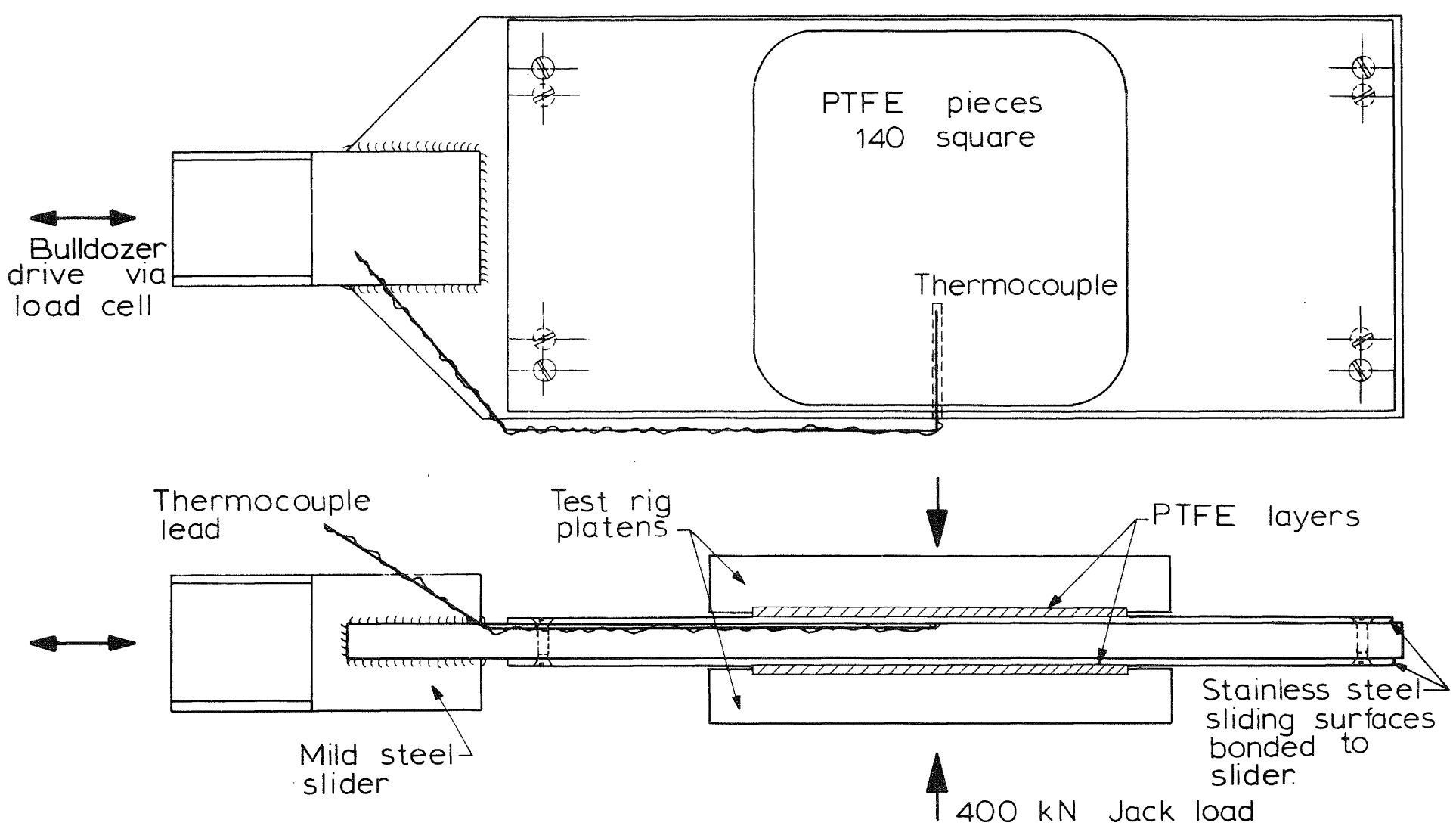


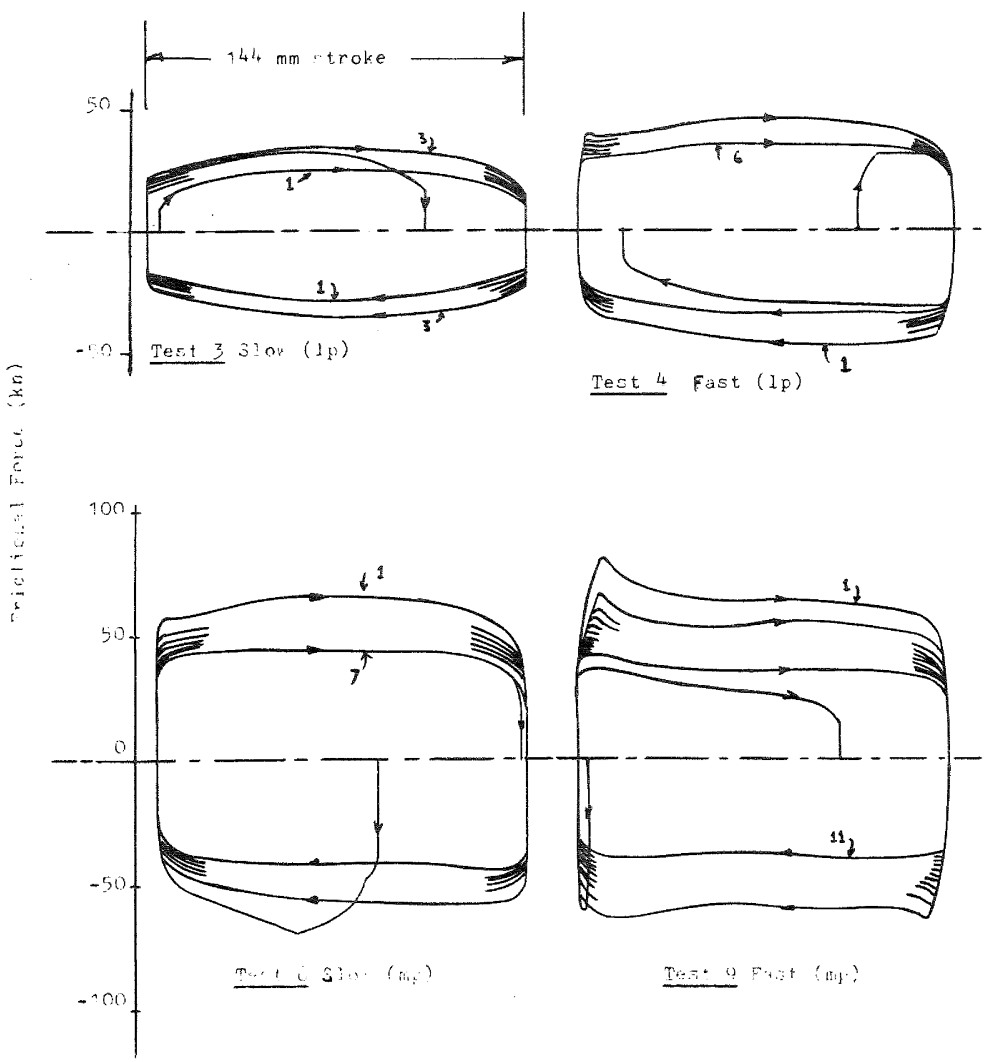

FIGURE 2: LOAD DISPLACEMENT RECORDS FOR LOW AND MEDIUM PRESSURE NB $1 p=$ low pressure

$\mathrm{mp}=$ medium pressure

hp $=$ high pressure

vhp = very high pressure SEE TABLE 1

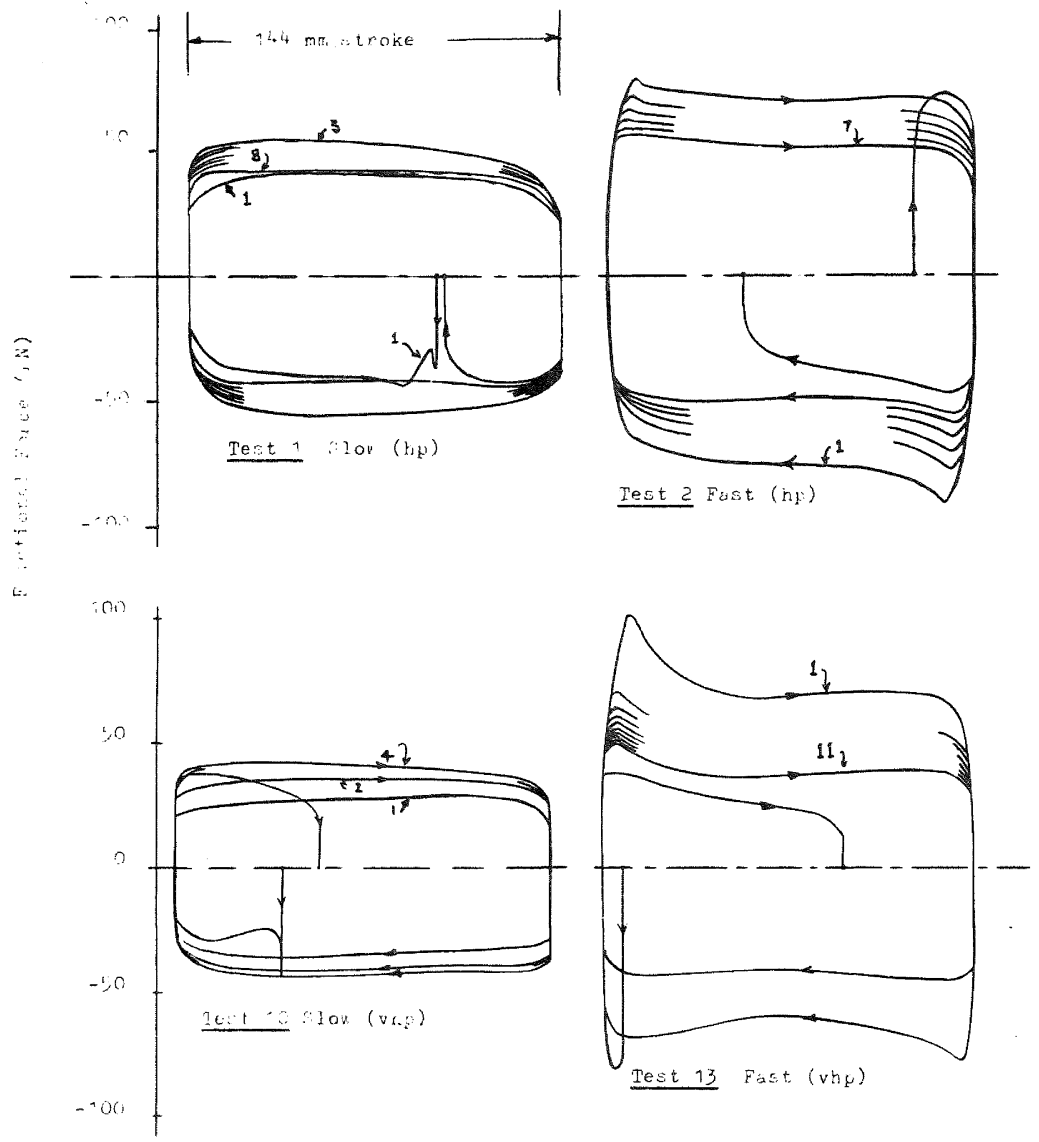

FIGURE 3: LOAD DISPLACEMENT RECORDS FOR HIGH AND VERY HIGH PRESSURES 

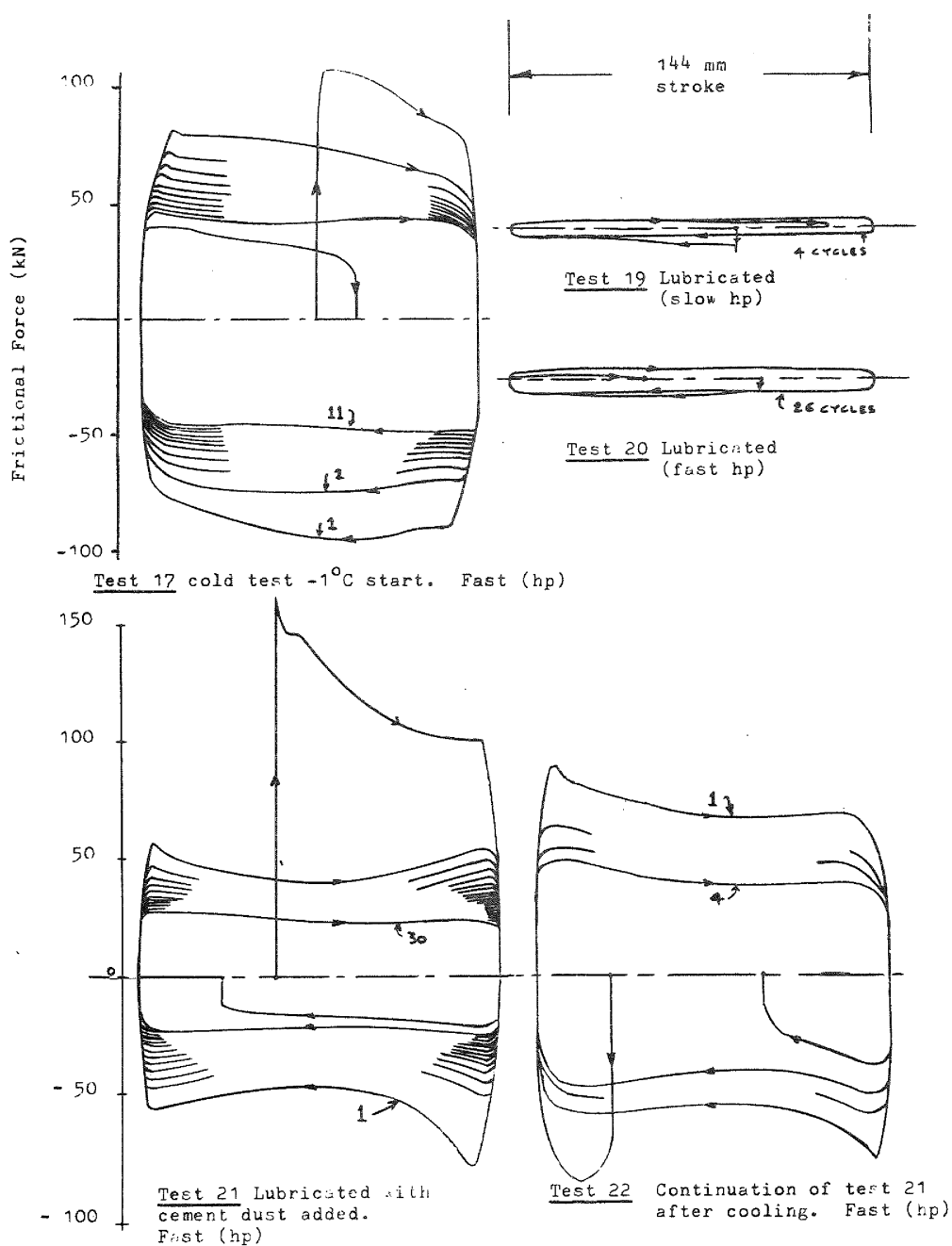

FIGURE 4: LOAD DISPLACEMENT RECORDS FOR COLD AND LUBRICATED CONDITIONS

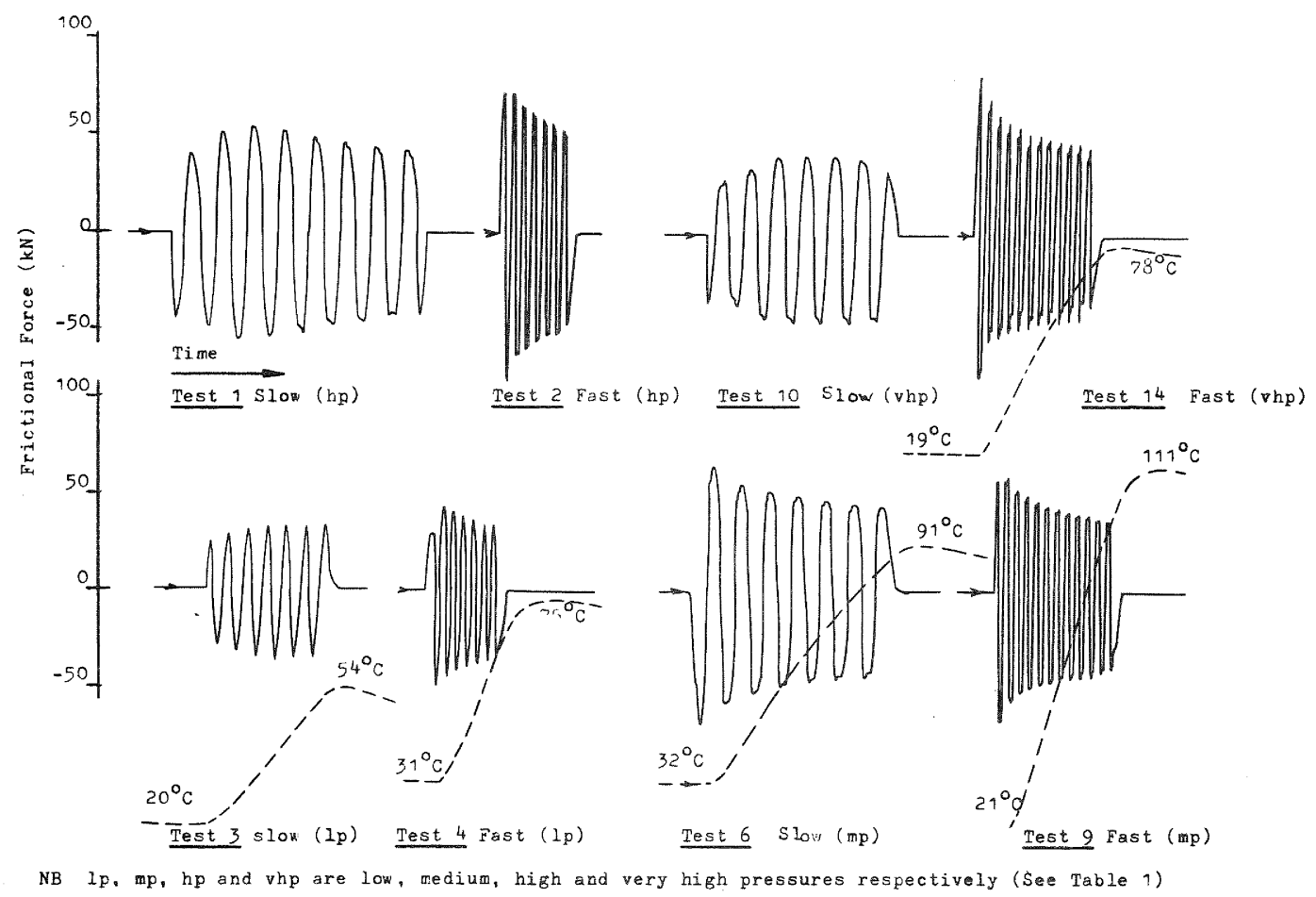




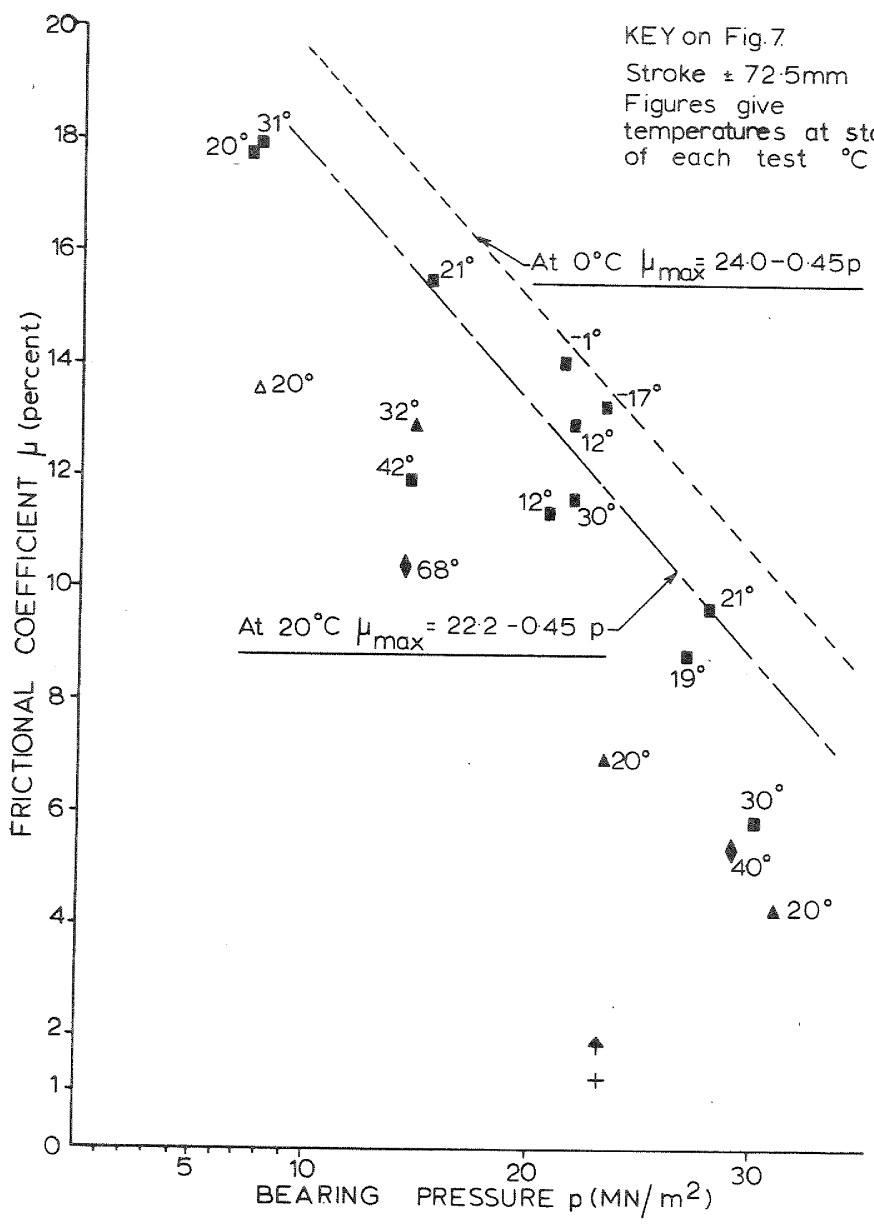

FIGURE 6: MAXIMUM VALUES OF DYNAMIC FRICTION RELATED TO BEARING PRESSURE

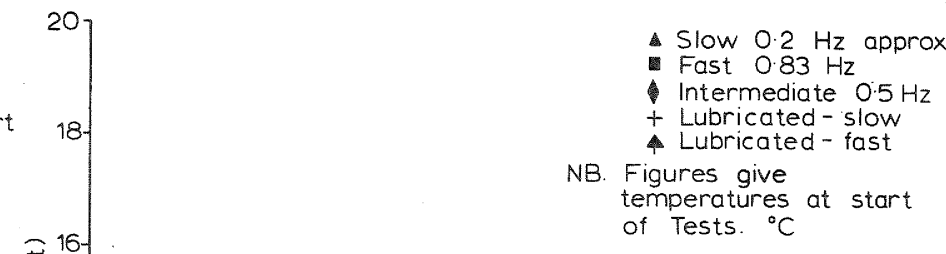

approx

$5 \mathrm{~Hz}$

Lubricated - fast

temperatures at start of Tests. ${ }^{\circ} \mathrm{C}$

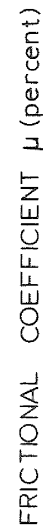

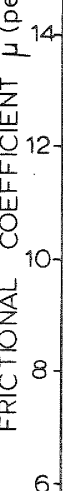

6

$2-$

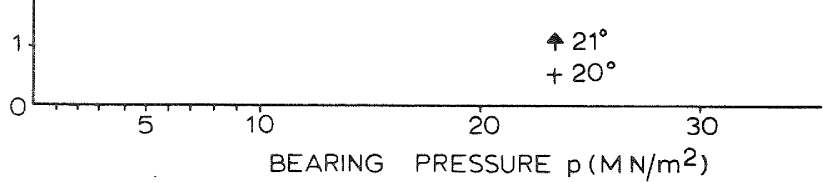

FIGURE 7: MAXIMUM DYNAMIC FRICTION VALUES FOR 6TH CYCLE 


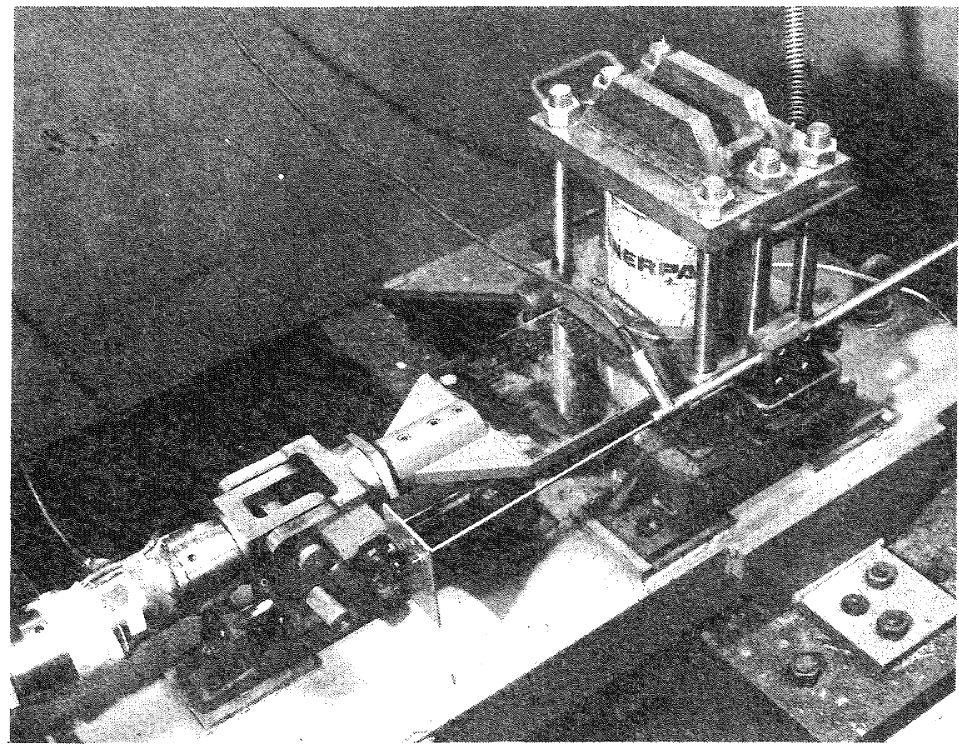

PLATE 1: PTFE RIG IN BULLDOZER

SNOWFLAKES OF PTFE ARE SEEN ON THE SLIDES

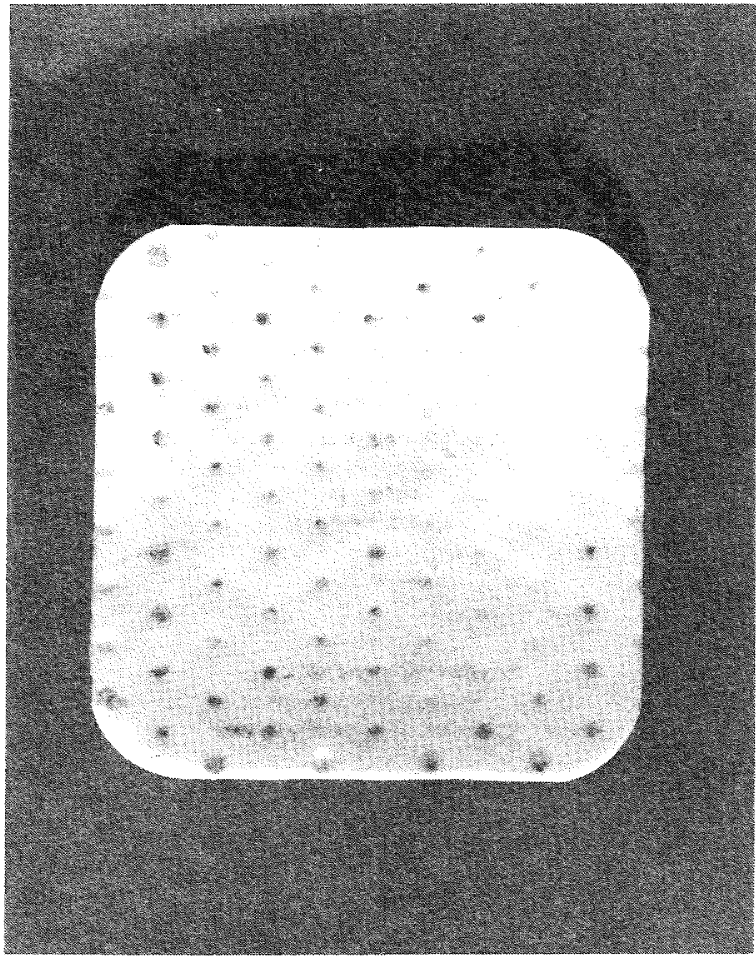

PLATE 3: PTFE AFTER TESTING UNDER DRY CONDITIONS

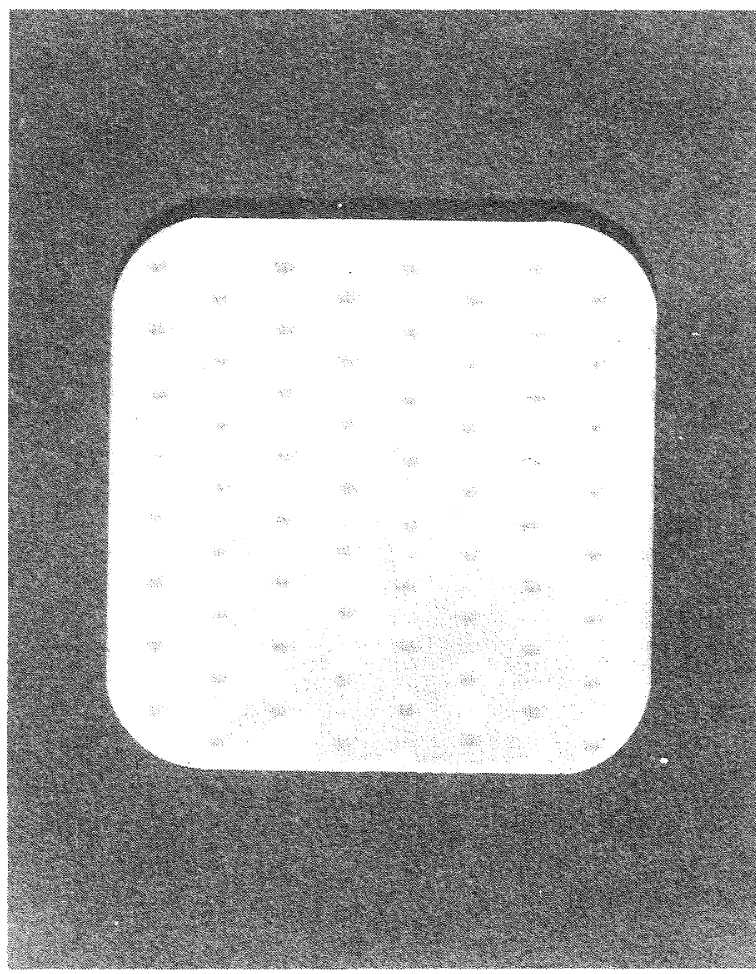

PLATE 2: PTFE BEFORE TESTING

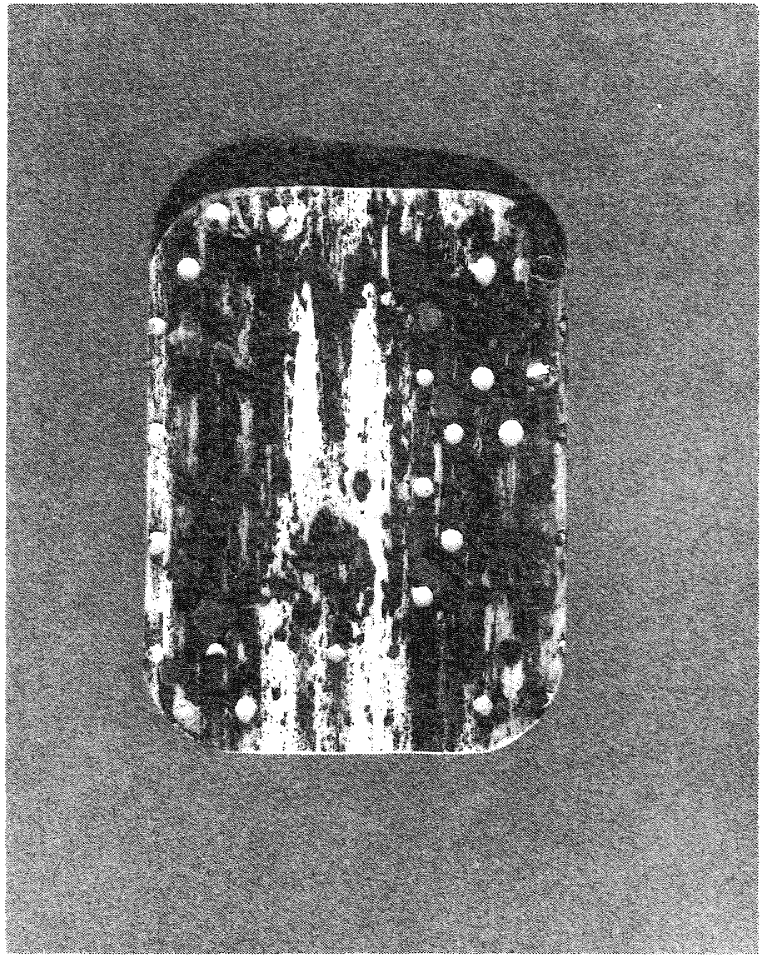

PLATE 4: PTFE AFTER GREASE AND CEMENT DUST TESTS 